\title{
Bovine Bone Charcoal as Support Material for Immobilization of Bacillus firmus Strain 37 and Production of Cyclomaltodextrin Glucanotransferase by Batch Fermentation in a Fluidized Bed
}

\author{
Larissa Albunio Silva ${ }^{1}$, Bruno Cesar Bieli², Osvaldo Valarini Junior ${ }^{1}$, Graciette Matioli ${ }^{3}$, \\ Gisella Maria Zanin1, Flavio Faria Moraes ${ }^{1}$ \\ ${ }^{1}$ Chemical Engineering Department, State University of Maringa, Maringá, Brazil \\ ${ }^{2}$ Graduate Program of Food Science, Universidade Estadual de Maringá, Maringá, Brazil \\ ${ }^{3}$ Pharmaceutical Sciences Department, State University of Maringa, Maringá, Brazil \\ Email: ^larissa_albunio@yahoo.com.br, bruno_bieli@hotmail.com, osvaldo_valarinijr@hotmail.com, gmatioli@uem.br, \\ gmzanin@uem.br,ffmoraes@uem.br
}

How to cite this paper: Silva, L.A., Bieli, B.C., Valarini Junior, O., Matioli, G., Zanin, G.M. and Moraes, F.F. (2018) Bovine Bone Charcoal as Support Material for Immobilization of Bacillus firmus Strain 37 and Production of Cyclomaltodextrin Glucanotransferase by Batch Fermentation in a Fluidized Bed. Advances in Chemical Engineering and Science, 8, 11-25. https://doi.org/10.4236/aces.2018.81002

Received: December 1, 2017

Accepted: January 28, 2018

Published: January 31, 2018

Copyright ( 92018 by authors and Scientific Research Publishing Inc. This work is licensed under the Creative Commons Attribution International License (CC BY 4.0).

http://creativecommons.org/licenses/by/4.0/

\section{(c) (i) Open Access}

\begin{abstract}
The process described in the present work uses air supplementation in a fluidized bed reactor containing Bacillus firmus strain 37 immobilized on active bovine bone charcoal, to produce by batch fermentation the enzyme CGTase (cyclomaltodextrin-glucanotransferase). Three different aeration rates were evaluated. The maximum CGTase activity was achieved after 120 hours of fermentation with aeration rate of $2 \mathrm{vvm}$ and was equal to $2.48 \mathrm{U} / \mathrm{mL}$. When 0.5 and $1 \mathrm{vvm}$ were used the enzymatic activities achieved 1.1 and $0.57 \mathrm{U} / \mathrm{mL}$, respectively. Bovine bone charcoal was characterized in terms of surface area, pore size and volume. To the best of our knowledge, the immobilization of microorganism cells in bovine bone charcoal for CGTase production has not been reported in the literature. Our results showed that fluidized bed reactor allows retaining high concentration of biomass, improving biomass-substrate contact and operation at low residence times, which resulted in improved enzyme production. Therefore, the process as proposed has great potential for industrial development.
\end{abstract}

\section{Keywords}

Bacillus firmus, Bone Charcoal Matrix, Cell Immobilization, Microbial Enzyme, Cyclomaltodextrin Glucanotransferase 


\section{Introduction}

The cyclomaltodextrin glucanotransferase ( $\alpha$-1,4-glucan-4-glucosyltransferase) is a bacterial enzyme which shows structural similarity with the enzyme $\alpha$-amylase [1] [2] [3]. The CGTase is considered a multifunctional enzyme, catalyzing four reactions: cyclization (intramolecular transglycosylation reaction), coupling (intermolecular transglycosylation reaction, wherein the cyclodextrin ring is ruptured and transferred to straight acceptors), disproportionation (where two linear oligosaccharides are converted into linear oligosaccharides of different sizes) and starch hydrolysis [4]. These reactions can be performed in a wide range of $\mathrm{pH}$ and temperatures, thus expanding the possibilities for industrial applications of CGTase [3].

In the industrial field the CGTase enzyme plays an important role due to its ability to catalyze the formation of cyclodextrins (CDs) from starch (cyclization reaction). CDs are cyclic maltooligosaccharides composed of $6-60$ glucose units linked by $\alpha$-1, 4-glycosidic bonds. They have the ability to form a variety of inclusion complexes with many organic and inorganic compounds, which is of interest for pharmaceutical, food, cosmetic, textile and agrochemical industries [2] [5].

Most common and commercially available CDs are those containing six $(\alpha-\mathrm{CD})$, seven $(\beta-\mathrm{CD})$, and eight $(\gamma-\mathrm{CD})$ anhydroglucose units. As CGTase produces preferentially $\alpha$-, $\beta$ - and/or $\gamma$-CD they are called as $\alpha$-, $\beta$ - and/or $\gamma$-CGTase. A CGTase that produces only one type of CD is not known, but a CGTase which produces a high proportion of one type of cyclodextrin is industrially favorable because it reduces the cost of the purifying process [2] [6] [7]. The kind of $\mathrm{CD}$ produced depends on culture parameters $(\mathrm{pH}$, temperature and aeration), enzyme producing microorganism and reaction time [8]-[13].

CGTase enzymes with different properties are produced mainly by members of the genus Bacillus, especially aerobic alkalophilics strains. Recently, alkalophilic bacilli aroused great interest because they are capable of producing $\beta$-CD and $\gamma$-CD without $\alpha$-CD accumulation. This makes the purification process much easier; $\beta$-CD and $\gamma$-CD have significant differences in terms of solubility [12] [14].

In addition to strain selection and culture parameters optimization, the improvement of GCTase production can be carried through cell immobilization in a fluidized bed reactor. Furthermore, immobilized cells allow reusing the biocatalysts and facilitate the separation of the liquid phase. Fluidization, on the other hand, reduces or eliminates obstruction problems and allows longer contact between the substrate and the biomass, reducing the need for large residence time in the reactors [15] [16]. To the best of our knowledge, the immobilization of microorganism cells in bovine bone charcoal for CGTase production has not been reported in the literature. This immobilization support is used, in most cases, in environmental research, such as the treatment of water contaminated by heavy metals or coloring agents, decomposition of organic pollutants, among 
others [9] [17] [18]. Bovine bone charcoal has hydroxyapatite (calcium phosphate) and minor amounts of calcium carbonate. The presence of carbonate gives the bovine bone charcoal a buffering capacity, wherein the $\mathrm{pH}$ is alkaline [17]. These properties are of great importance, since the culture medium of $B$. firmus strain 37 and CGTase production have $\mathrm{pH}$ between 9 and 11. Bovine bone charcoal has aroused great interest in the immobilization of cells, due to its high porosity, which allows the microorganisms not just to colonize and grow on the surface of the support, but also inside its cracks, adding to the process biomass load and increasing production of products with higher added value [19] [20].

Enzyme production in immobilized processes face diffusional problems related to the porosity of the matrix [8]. The use of matrices that do not impose such problems are of great benefit and will probably result in better productivities. Pazzetto [21] showed that diffusional problems are severe when alginate beads were used for the immobilization of Bacillus firmus, differently from the experiments carried with sponge plant, which is a highly porous material. Based on these observations, different aeration rates were evaluated for the production of CGTase with Bacillus firmus immobilized in bovine bone charcoal.

In this paper, it was evaluated the batch production of high activity CGTase with Bacillus firmus strain 37 immobilized in bone charcoal and used in an aerated fluidized bed reactor with recycle. The effects of different aeration rates during the production of CGTase activity were also assessed and discussed. Additionally, it was investigated the characteristics of bovine bone charcoal as an innovative support for immobilization of microorganisms in the area of enzyme production. Similarly, it was addressed the performance of cell immobilization in bone charcoal using the same aeration rates for enzymatic production.

\section{Materials and Methods}

\subsection{Schematic Diagram of the Aerobic Fluidized Bed Reactor}

Figure 1 shows the schematic diagram of the jacketed fluidized bed reactor used for producing CGTase. A reactor with an internal column volume of approximately $140 \mathrm{~cm}^{3}$ was used in a recycle batch mode. The fluidized bed column in the reactor had an internal diameter of $2.1 \mathrm{~cm}$ and the column height was $40 \mathrm{~cm}$. The thermostatic bath was set to $37^{\circ} \mathrm{C}$ and warm water recirculated through the column jacket. A cultivation medium reservoir of $2 \mathrm{~L}$ was used. Different forced aeration rates were tested for CGTase production by the selected microorganism, which was immobilized in bone charcoal particles.

\subsection{Microorganism and Culture Conditions}

The microorganism used was Bacillus firmus strain 37, isolated from the soil of manioc plantation and identified by Matioli [22]. The microorganism is strictly aerobic and presents optimum growth at $37^{\circ} \mathrm{C}$ and $\mathrm{pH}$ between 9 and 11 [22]. Bacillus firmus strain 37 was stored in packed sterilized soil at room temperature. 


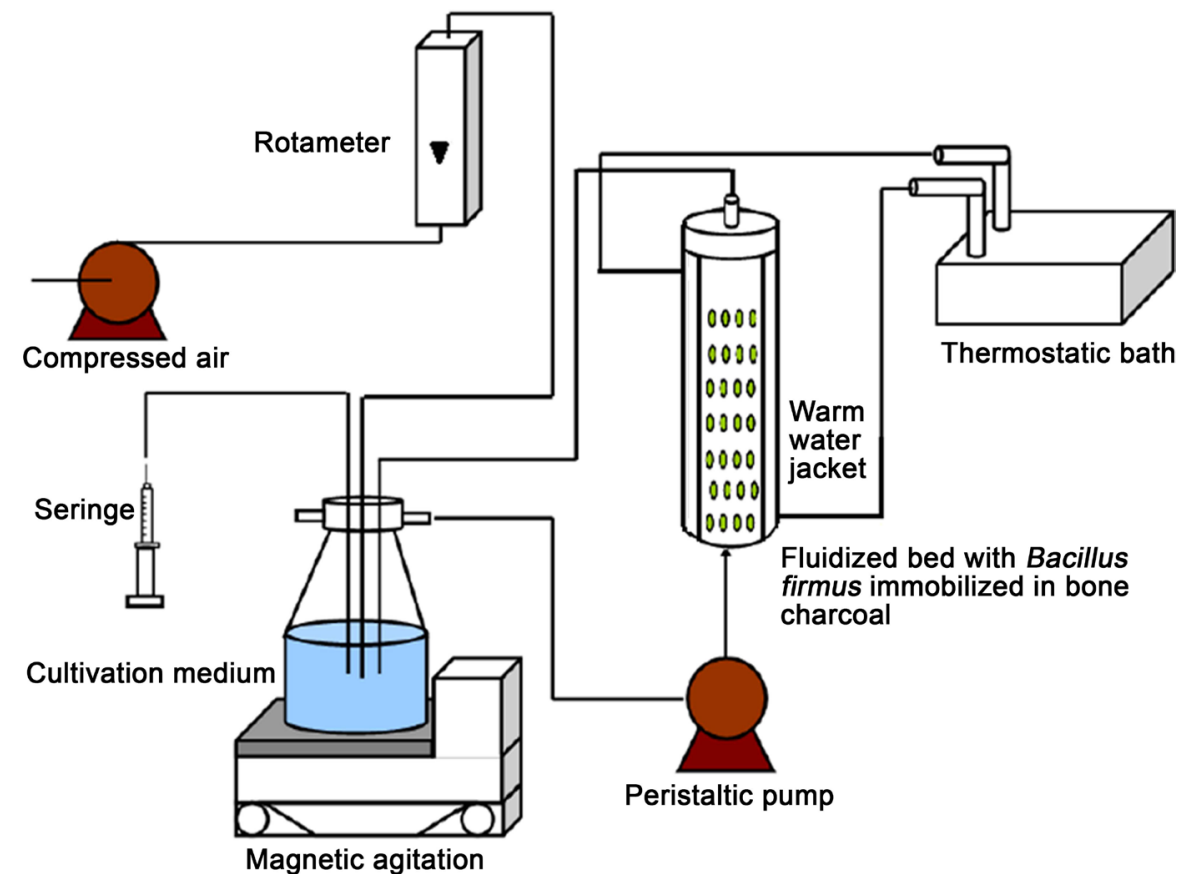

Figure 1. Schematic diagram of the fluidized reactor containing bone charcoal particles with immobilized cells of Bacillus firmus strain 37.

For the microorganism reactivation it was first grown at $37^{\circ} \mathrm{C}$ for $48 \mathrm{~h}$ on solid medium with the following composition $(\mathrm{w} / \mathrm{v})$ : soluble starch $1.0 \%$, polypeptone $0.5 \%$, yeast extract $0.5 \%$, potassium phosphate $0.1 \%$, magnesium sulfate heptahydrate $0.02 \%$, sodium carbonate $1.0 \%$, agar $1.5 \%$ and congo red $0.01 \%$ [22] [23]. The bacillus cells were transferred to a liquid medium with the same composition of the solid medium, except for agar, dye and starch (in the liquid medium starch was used in $2 \%(\mathrm{w} / \mathrm{v})$ concentration). The liquid culture was maintained in an incubator at $140 \mathrm{rpm}$ and $37^{\circ} \mathrm{C}$ for $24 \mathrm{~h}$.

\subsection{Preparation and Characterization of the Cell Immobilization Matrix}

Bovine bone charcoal samples were provided by the company Bonechar - Carvão Ativado do Brasil. The charcoal particles were first sieved in the range of 20 to 28 Mesh (0.83 and $0.58 \mathrm{~mm}$, respectively), washed repeatedly with deionized water to remove soot and then dried in an oven for 24 hours at $100^{\circ} \mathrm{C}$. The characterization of bovine bone activated charcoal was carried by isotherms adsorption of $\mathrm{N}_{2}$ to estimate specific area through B.E.T. (Brunauer-Emmett-Teller) model. Other physicochemical properties determined are given in the results.

\subsection{Cell Immobilization Process}

The liquid culture of Bacillus firmus was diluted with fresh liquid medium to achieve an $\mathrm{OD}_{660 \mathrm{~nm}}$ (optical density) between 0.4 and 0.6. This was mixed with 7 grams of sterile bone charcoal in the fluidized bed reactor of Figure 1. The microorganism immobilization occurred naturally as the fluidized bed was run for 
24 hours in a batch recirculation mode. Experiments were carried using three different aeration rates $(0.5,1$, and $2 \mathrm{vvm}$ ) (volume of air per volume of medium per minute).

\subsection{Production of CGTase}

Production of CGTase was carried out in the same fluidized bed reactor used for the cell immobilization process, after the immobilization process (Section $2-4$ ) finished.

The aeration rate in each case was $0.5,1$ and $2 \mathrm{vvm}$ and the production time was 120 hours. Soluble starch was used as substrate in these experiments.

\subsection{Analytical Methods}

\subsubsection{Scanning Electron Microscopy (SEM)}

The bone charcoal with the immobilized cells was placed in a solution of $2.5 \%$ glutaraldehyde for 24 hours. The supernatant was then discarded and this charcoal was sequentially washed four times, for 10 to 15 minutes, with ethanol solutions $30 \%, 50 \%, 70 \%, 90 \%$ and $100 \%$, respectively. The material was kept in absolute ethanol for dehydration and subsequently extracted with $\mathrm{CO}_{2}$ supercritical. For the micrographs, a scanning electron microscope with an accelerating voltage of $10 \mathrm{kV}$ was used. The samples were placed on the surface of a conductive double sided tape and coated with gold [2].

\subsubsection{Protein Determination}

The protein concentration for the analysis was measured by the method of Lowry [24] using bovine serum albumin as standard.

\subsubsection{Determination of $\beta$-CD}

Concentration of $\beta$-cyclodextrin $(\beta$-CD) was determined using a colorimetric method in which a phenolphthalein solution is mixed with the cyclodextrin sample, leading to the formation of a complex between the dye molecule and the cyclodextrin. This complexation reduces the color intensity of the mixed solution and absorbance is measured at $550 \mathrm{~nm}$ [25] [26].

The assay was performed by mixing $0.5 \mathrm{~mL}$ of the sample to $2.5 \mathrm{~mL}$ of a working solution composed of phenolphthalein $0.06 \mathrm{mM}$, sodium carbonatebicarbonate buffer $0.6 \mathrm{M}, \mathrm{pH}$ 10.5. Phenolphthalein $0.06 \mathrm{mM}$ solution was prepared fresh using $2 \mathrm{~mL}$ of $95 \%$ ethanol phenolphthalein $3 \mathrm{mM}$ stock solution, 20 $\mathrm{mL}$ of sodium carbonate-bicarbonate buffer and volume completed to $100 \mathrm{~mL}$.

$\beta$-CD concentration correlates with the absorbance according to Equation (1) $[25]$.

$$
C_{\beta-\mathrm{CD}}=a\left[1-\frac{A B S}{A B S_{o}}\right]\left[1+\frac{A B S_{o}}{a k A B S}\right]
$$

where $a$ is the total concentration of the assay phenolphthalein $\left(5 \times 10^{-5} \mathrm{M}\right)$. ABS is the absorbance of the sample mixed with the phenolphthalein solution; $A B S_{o}$ is the absorbance of the sample without cyclodextrin and mixed with the phe- 
nolphthalein solution; $C_{\beta-\mathrm{CD}}$ is the concentration of $\beta$-CD expressed in $\mathrm{mM}$; and $k$ is the equilibrium constant of complex formation $\beta$-CD/phenolphthalein. The value of $k$ was determined by nonlinear regression (Quasi-Newton method), using a standard concentration of $\beta$ - $\mathrm{CD}\left((0-1) \times 10^{-3} \mathrm{M}\right)$ made up in distilled water, resulting in $14495.2 \mathrm{M}^{-1}$, with a correlation coefficient of 0.9976 .

Equation (2) was obtained by replacing the value of $a, k$, and the value $A B S_{o}=$ 1.4815 in Equation (1) and multiplying the resulting equation by a factor equal 6000 , which is related to the dilution procedure (converts $\mathrm{M}$ in $\mathrm{mM}$, the unit of concentration of $\beta$-CD).

$$
C_{\beta-\mathrm{CD}}=0.3000(1-0.6750 \mathrm{ABS})\left(1+\frac{2.0442}{\mathrm{ABS}}\right)
$$

Concentration of $\beta$-CD in $\mathrm{mM}$ is then determined by Equation (2), with absorbance (ABS) in the range of $0.50-1.481$ and resulting $\beta$-CD concentration range of $0-1 \mathrm{mM}$. Note, however, that as cyclodextrin concentration increases in the sample, the absorbance of the assay mixture reduces, because the CDphenolphthalein complex is colorless.

\subsubsection{Volumetric Enzymatic Activity}

The enzyme activity is determined by the Initial Velocity Method, according to Hamon and Moraes [27], under the following conditions: $50^{\circ} \mathrm{C}$ (for activation of the enzyme), $\mathrm{pH} 8.0$ (greater enzyme stability) and low concentrations of enzyme (up to $0.4 \mathrm{mM}$ ), then in these conditions the concentration of $\beta$-CD produced as function of time follows a linear relationship.

The substrate stock solution was made using $1 \%$ dextrin, dissolved in $50 \mathrm{~mL}$ of stock solution of $\mathrm{CaCl}_{2}(5 \mathrm{mM})$ and $100 \mathrm{~mL}$ of Tris- $\mathrm{HCl}$ buffer $(0.05 \mathrm{M}, \mathrm{pH}$ 8.0). Volume was completed to $500 \mathrm{~mL}$. The enzyme samples were diluted with Tris-HCl buffer and $\mathrm{CaCl}_{2}$ stock solution, if necessary, in order to guarantee the linearity of responses. The dosing tubes containing $1.0 \mathrm{~mL}$ of substrate were placed on a bath at $50^{\circ} \mathrm{C}$ for 15 minutes. To these tubes $1.0 \mathrm{~mL}$ of enzymatic medium were added, according to the reaction time of each tube (from 0 to 30 minutes). Then the tubes were placed in a bath at $100^{\circ} \mathrm{C}$ for $5 \mathrm{~min}$ to inactivate the enzyme and then cooled in water at ambient temperature. Subsequently, the colorimetric measurements were performed by adding a sample of $0.5 \mathrm{~mL}$ from these tubes to $2.5 \mathrm{~mL}$ of phenolphthalein $0.06 \mathrm{mM}$.

The production data of $\beta$-cyclodextrin ( $\mu$ moles $\mathrm{CD}$ produced per $\mathrm{mL}$ of cell free culture per min) were plotted as a function of reaction time. The slope of the straight line $(K)$ was used to calculate the volumetric activity, using Equation (3):

$$
A=\left(K \cdot V_{R} \cdot D\right) / V_{E}
$$

where: $A=$ volumetric activity in $\mu$ moles $\mathrm{CD} /(\mathrm{min} \cdot \mathrm{mL}$ of enzyme solution), $K=$ slope of the concentration of CDs produced as a function of reaction time ( $(\mu$ moles $\mathrm{CD} /(\mathrm{mL} \cdot \mathrm{min})), D=$ dilution of enzymatic media, $V_{R}=$ reaction volume in $\mathrm{mL}$, or the diluted enzyme volume present in a test tube, $V_{E}=$ total reaction volume in $\mathrm{mL}$. 
One unit ( $\mathrm{U})$ of activity is considered the enzyme amount that catalyzes the conversion of one $\mu \mathrm{mol}$ of substrate (or producing one $\mu \mathrm{mol}$ of product) per minute, in the reaction conditions ( $\mathrm{pH} 8$ and $50^{\circ} \mathrm{C}$ ).

All experiments of enzyme activity were performed in triplicate.

It is worth mentioning that the values chosen for the large number of parameters in this study are based on previous theses, dissertations and papers published by the research group that has been working in the area of cyclodextrins since 1990 and with fluidization since 1980. The choice of parameters was made with the goal of increasing the production of the enzyme cyclomaltodextrin glucanotransferase (CGTase).

\section{Results and Discussion}

SEM (Scanning electron microscopy) results for microorganism immobilization estimated bacteria size of $0.5 \mu \mathrm{m} \times 5 \mu \mathrm{m}$ [2]. The specific surface area of charcoal was found to be $123.5 \mathrm{~m}^{2} / \mathrm{g}$, while the total pore volume was equal to 0.277 $\mathrm{cm}^{3} / \mathrm{g}$ and the average pore diameter was $89.85 \AA\left(0.008985 \times 10^{-4} \mu \mathrm{m}\right)$. These values are in accordance with previous studies [17] [28]. Considering that the diameter of the charcoal pores is many times smaller than the cell of $B$. firmus strain 37, there is little chance that the bacteria was adsorbed inside the pores, except when there are cracks in the charcoal and the microorganism can settle inside these, reproduce and produce enzyme. This means that the immobilization of most cells occurred by adsorption on the surface of bone charcoal, which was confirmed by SEM microscopy (Figure 2).

Figure 2(a) showed roughness and the presence of micropores on the surface of the charcoal. The particle microporosity is in agreement with the pore diameter

(a)

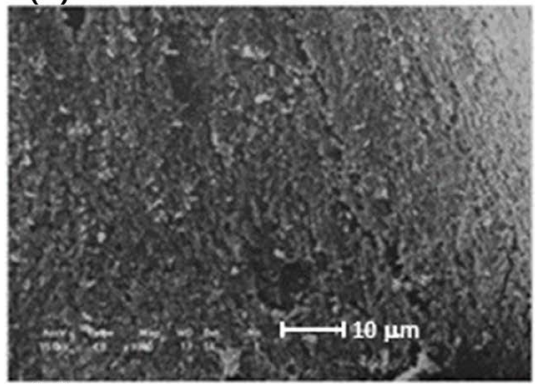

(c)

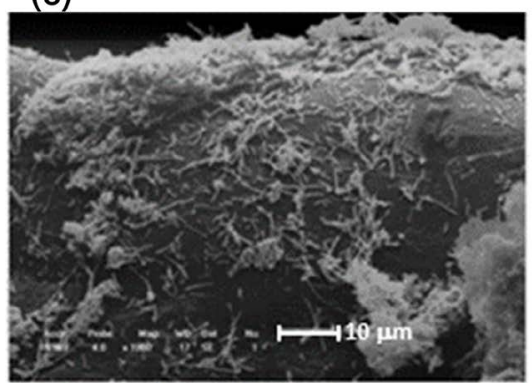

(b)

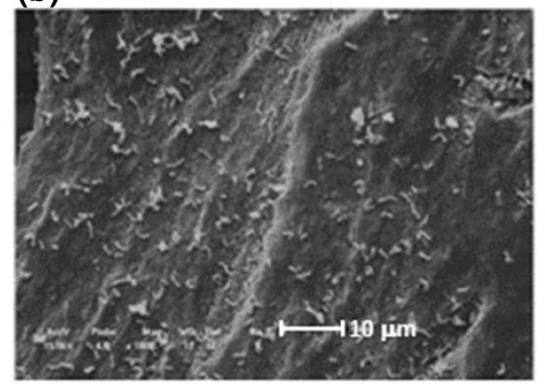

(d)

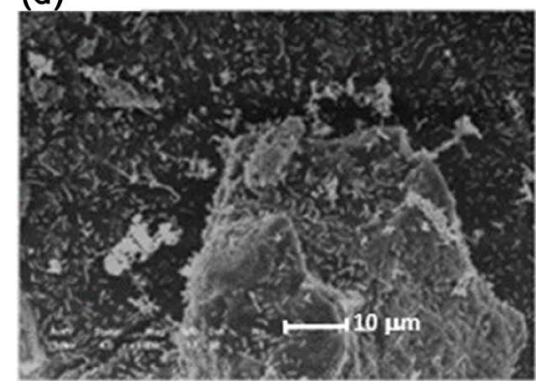

Figure 2. Scanning electron microscopy. Cell-free bone charcoal (a); Immobilized cells in bone charcoal in different aeration rates: $0.5 \mathrm{vvm}$ (b) $1 \mathrm{vvm} \mathrm{(c)} \mathrm{and} 2 \mathrm{vvm}$ (d). 
average found in our study $\left(89.85 \AA\right.$ or $\left.0.008985 \times 10^{-4} \mu \mathrm{m}\right)$. In addition, it was possible to note on the microscopy of bioparticles (bone charcoal + immobilized microbial cells) (Figures 2(b)-(d)) the adhered rod-shaped microorganisms, probably Bacillus firmus, in the activated bone charcoal, proving the success of cell immobilization. Biofilm formation involves a number of physical, chemical and biological processes, including, among others: the adsorption of organic molecules on a surface, the movement of cells to the surface, the adhesion of microorganisms to the surface, the subsequent adhesion to the first layer of cells, the accumulation of the resulting biofilm and the release of the biofilm. It is known that this process is extremely complex, and that still remains many aspects that need to be clarified [29] [30].

CGTase production with Bacillus firmus immobilized in $7 \mathrm{~g}$ of bone charcoal using the fluidized bed system with recycle in batch was performed first with aeration rate of $0.5 \mathrm{vvm}$ (Figure 3 ).

The specific CGTase activity reaches a maximum value of approximately 1 $\mathrm{U} / \mathrm{mL}$ and $0.3 \mathrm{U} / \mathrm{mg}$ protein (Figure 3 ) at 120 hours. It was noted that CGTase activity remained relatively constant between 48 and 108 hours. The slight increase in the specific activity at 120 hours of fermentation is in accordance to Vassileva [31], indicating that the culture conditions set forth provides protein synthesis and consequently enzyme. According to Atanasova [32], CGTase is an extracellular enzyme and the specific enzyme activity (U/mg protein) shows that part of the total protein is enzyme. Often what is established is that high volumetric CGTase activity quantities $(\mathrm{U} / \mathrm{mL})$ in the presence of high amounts of total protein means less low specific activity, i.e., fewer enzyme molecules per volume will be present in the culture medium/output. Atanavosa [32] performed immobilization of Bacillus pseudalcaliphilus 20RF and Bacillus pseudalcaliphilus 8SB in agar gel containing magnetite for CGTase production and achieved a production of 0.14 and $0.2 \mathrm{U} / \mathrm{mL}$, respectively, lower than the activity achieved in this study. The same authors [33] carried experiments with the isolated strain Bacillus pseudalcaliphilus 20RF, reaching low enzymatic activity in the crude

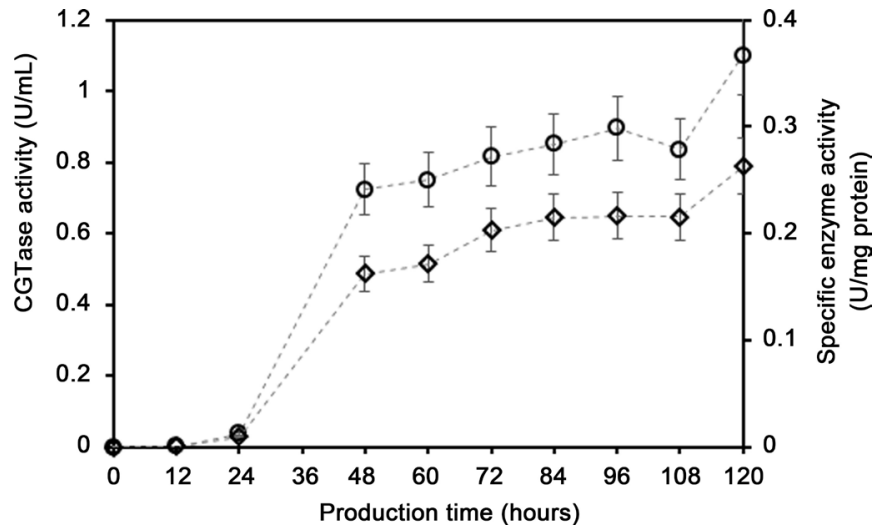

Figure 3. CGTase activity (circle) and specific CGTase activity (diamond) as a function of time of fermentation with Bacillus firmus immobilized in bone charcoal and aeration rate of $0.5 \mathrm{vvm}$. 
extract $(0.007 \mathrm{U} / \mathrm{mL})$. In the purified extract they achieved a very high enzymatic activity of $0.66 \mathrm{U} / \mathrm{mL}$, close to the results found in the crude extract of the current study.

The next aeration rate tested for enzyme production was $1 \mathrm{vvm}$. It was noted that the process was severely affected, resulting in lower enzyme activity (Figure 4). When aeration was provided at $1 \mathrm{vvm}$, the enzyme activity reached a maximum of $0.57 \mathrm{U} / \mathrm{mL}$, after remain constant $(0.36 \mathrm{U} / \mathrm{mL})$ in the interval time of 72 and 96 hours.

Vassileva [34] worked with CGTase production with Bacillus circulans immobilized in agar. They carried experiments in batch without aeration, reaching a CGTase activity of approximately $0.15 \mathrm{U} / \mathrm{mL}$ at 72 hours of fermentation. Kuo [35] studied CGTase production in batch with non-immobilized Bacillus sp. without air supplementation and found a very high enzymatic activity of 13 $\mathrm{U} / \mathrm{mL}$ at 15 hours. This reinforce the fact that microbial immobilization may impose barriers against oxygen and mass transfer, which might be considered in process design. On the other hand, industrial production of enzyme with freecell continuous process fermentation is not usually adequate [36]. Moriwaki [4] studied batch CGTase production using Bacillus sphaericus strain 41 and achieved a maximum enzyme activity of $0.048 \mathrm{U} / \mathrm{mL}$ at 120 hours. All these comparisons indicate that there are several factors interfering in enzyme production. According to Ibrahim [37], the quality and origin of starch used may interfere in enzyme production, because it can increase the viscosity of the medium, resulting in improper mixing and reducing the rate of mass transfer.

To further evaluate the effect of aeration in CGTase production, an experiment was carried with aeration rate of $2 \mathrm{vvm}$ (Figure 5).

Figure 5 presents the results of higher aeration in CGTase production using B. firmus strain 37 immobilized in bovine bone charcoal. It can be observed a great increase in enzyme activity, reaching $2.48 \mathrm{U} / \mathrm{mL}(0.48 \mathrm{U} / \mathrm{mg}$ protein). CGTase production was more efficient when the higher aeration rate was used (2 $\mathrm{vvm}$ ), increasing the activity by $1.38 \mathrm{U} / \mathrm{mL}$ in 120 hours. Moreover, the enzyme

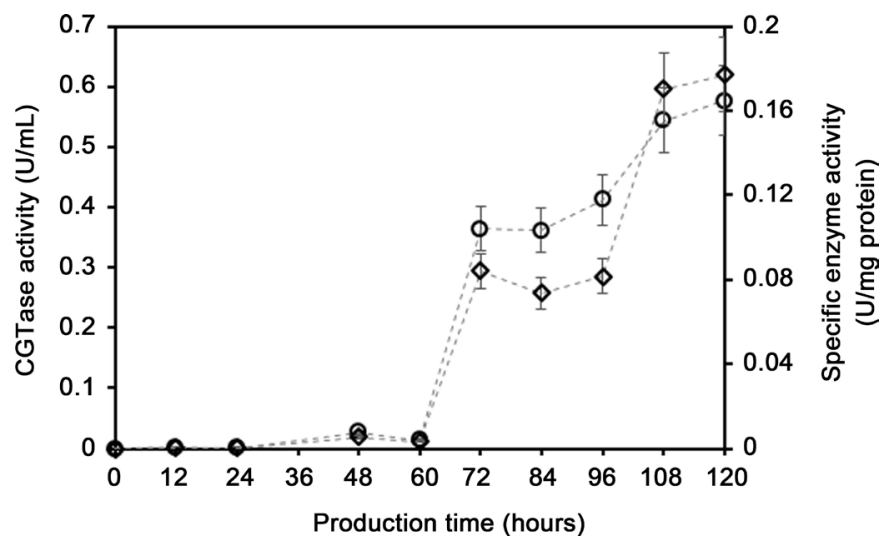

Figure 4. CGTase activity (circle) and specific (diamond) as a function of time of fermentation carried with Bacillus firmus immobilized in bone charcoal and aeration rate of $1 \mathrm{vvm}$. 


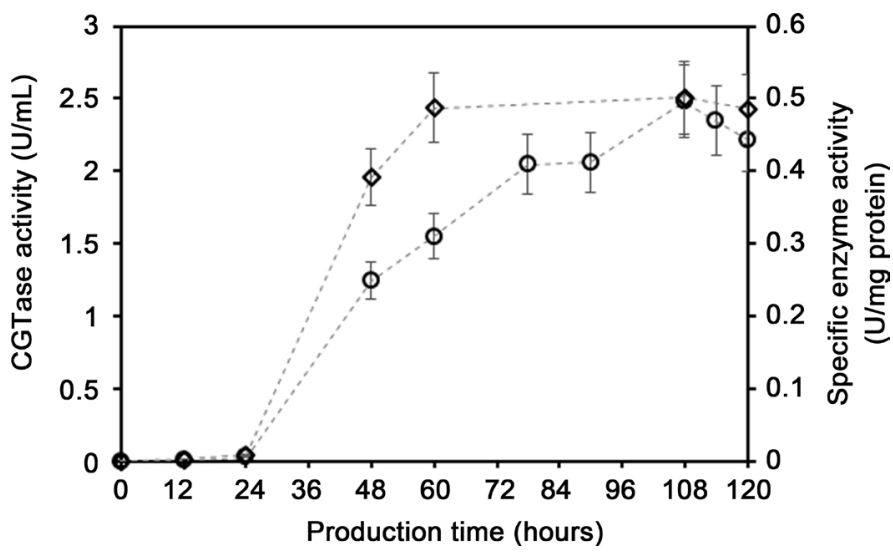

Figure 5. CGTase activity (circle) and specific (diamond) as a function of time of CGTase produce with Bacillus firmus immobilized in bone charcoal and aeration rate of $2 \mathrm{vvm}$.

Table 1. CGTase production Bacillus firmus strain 37 immobilized in bone charcoal in three aeration rates.

\begin{tabular}{ccc}
\hline $\begin{array}{c}\text { Aeration rates } \\
\text { (volume of air/volume de medium * minute) }\end{array}$ & $\begin{array}{c}\text { CGTase activity } \\
(\mathrm{U} / \mathrm{mL})\end{array}$ & $\begin{array}{c}\text { Specific Enzyme Activity } \\
(\mathrm{U} / \mathrm{mg} \text { protein })\end{array}$ \\
\hline 0.5 & 1.1 & 0.27 \\
1 & 0.57 & 0.17 \\
2 & 2.48 & 0.48 \\
\hline
\end{tabular}

activity reached $1 \mathrm{U} / \mathrm{mL}$ in just 36 hours of fermentation (Figure 4), different from the experiment carried with $0.5 \mathrm{vvm}$ of aeration $(1 \mathrm{U} / \mathrm{mL}$ was reached only at 120 hours). These results prove the importance of aeration rate for the production of CGTase in lower times or to reach higher. The relationship between aeration rate and CGTase production achieved in this study is presented in $\mathrm{Ta}$ ble 1.

It can be observed that, increasing the aeration rate to $2 \mathrm{vvm}$ specific and notspecific CGTase activity approximately doubled. This indicates that the aeration rates of 0.5 and $1 \mathrm{vvm}$ were not supplying enough $\mathrm{O}_{2}$ to the cells. Kunamneni [14] using Bacillus sp. immobilized in calcium alginate and airlift reactor for CGTase production also reported that the higher enzyme activity was achieved at aeration rate of $2 \mathrm{vvm}$.

The smaller effect of $1 \mathrm{vvm}$ aeration rate at the production of CGTase can be explained according to Moriwaki [4], who stated that this can favor microbial growth at detriment of the production of CGTase and that the high biomass concentration in charcoal resulted in a decrease of the dissolved oxygen in the medium (consequently lowering enzyme production). Blanco [38] reported that lower values of dissolved oxygen and rate of agitation may limit the uptake of nutrients by the microorganisms (such as the nitrogen source and starch), decreasing the synthesis of CGTase.

The authors Pinto et al. [3] have studied the production of CGTase using free Bacillus circulans under agitation and aeration and reported that best enzyme 
activity, approximately $0.5 \mathrm{U} / \mathrm{mL}$, was obtained at $400 \mathrm{rpm}$ and $1 \mathrm{vvm}$. During their study they concluded that agitation and aeration are decisive parameters for microbial growth and enzyme production, playing an important role in scaling up. The importance of the effect of aeration on production of CGTase was more evident when the same authors [39] increased the aeration rate to $2 \mathrm{vvm}$, but kept the agitation at $400 \mathrm{rpm}$. The result was a very significant increase in the enzymatic activity, which reached $1 \mathrm{U} / \mathrm{mL}$.

It is important to highlight that, in our study, aeration was not the only parameter essential for higher enzymatic activity production, but also cellular immobilization in the bovine bone charcoal and the use of a fluidized bed reactor. The process of biofilm formation on the surface of the support is initiated by suspended cells present in the liquid medium, which are adsorbed on the surface and then grow as a biofilm. As suspended cells initiate biofilm formation, the concentration of cells in the media has a significant effect for starting biofilm formation, since allows colonization of a larger number of particles on the support [20] [29].

Biofilm formation, among other factors, is linked to the velocity of flow on the surface. Among the advantages of usage of the fluidized bed is the biomass growth in films of reduced thickness, which improves the mass transfer. In addition, fluidization reduces or eliminates clogging problems, increases biomass retention and contact with the substrate and therefore reduces the residence time in the reactors. These characteristics make the aerobic fluidized bed reactor a good choice for the production of enzyme with immobilized cells. Other factors that contribute to the efficiency of the fluidized bed process are: greater contact between the liquid medium and the solid of the biofilm carrier when compared to fixed bed (due to particle movement and liquid velocity, the diffusional resistance of the liquid is minimum); problems of preferential channels and agglomeration of particles, often found in fixed bed, are avoided; ability to control and optimize biofilm thickness; need for a smaller cross-sectional flow area [15] [20] [30].

Thus, it can be concluded that the use of bovine charcoal as support material for the immobilization of Bacillus firmus strain 37 and production of CGTase in a fluidized bed bioreactor with high aeration rate is indicated for achieving high activity of the enzyme. Our results indicate that the process described in this work has great potential for industrial batch production of CGTase with greater concentration than traditional submerged culture fermentation. We found that this reactor allows retaining high concentration of biomass, improving biomasssubstrate contact and allowing operation at low residence times.

\section{Conclusions}

In this work, the conditions to obtain a high production of the enzyme cyclomaltodextrin glucanotransferase (CGTase) by a recirculating fluidized bed of Bacillus firmus strain 37 immobilized on small particles of bovine bone charcoal 
were determined. It was demonstrated that higher CGTase activity $(2.48 \mathrm{U} / \mathrm{mL}$, $0.48 \mathrm{U} / \mathrm{mg}$ protein) can be achieved by working with greater aeration rates (2 $\mathrm{vvm})$. However, further studies are necessary to observe up to which point it will be advantageous to increase aeration rates, because it is expected that a limiting condition may be reached, in which, instead of favoring the production of greater amounts of CGTase, a large amount of microbial growth will result.

The study of the reuse of bovine bone charcoal with immobilized Bacillus firmus is recommended. Appropriate conditions of storage of this biocatalyst and the determination of a maximum possible stocking time, in which, only minor losses in the production of the enzyme would occur are important for producing CGTase as desired and without going to the immobilization process every time.

In this work it was shown that Bacillus firmus fixed in bone charcoal has a prominent role in CGTase production, since the charcoal does not impose diffusional barriers like other supports described in the literature. For industrial development of this technology the low cost of bone charcoal would also be an advantage.

The results of the present work warrant the possibility of increasing the scale of production, because greater amounts of enzyme could be produced at lower cost with this technology and as a consequence, cyclodextrins would be produced more economically. If cyclodextrins would reach the market at lower prices than today (U\$5/ton), many potential, large volume applications could became a reality.

Some guideline goals for industrial development would be to try to achieve sufficient large bed size, fluidization just above minimum fluidization velocity and high rate of enzyme production with optimum aeration rate, to verify it would be possible to operate in a single pass mode, that is, without fluid recycle.

\section{Acknowledgments}

The authors are thankful to the Brazilian Agency CAPES for the financial support of this work.

\section{References}

[1] Matioli, G., Moriwaki, C., Mazzoni, R.B., Zanin, G.M. and Moraes, F.F. (2000) Study of Parameters That Influence the Production of the Enzyme CGTase from Bacillus firmus, Strain no 37. Acta Scientiarum Biological Sciences, 22, 311-316.

[2] Moriwaki, C., Pelissari, F.M., Gonçalves, R.A.C., Gonçalves, J.E. and Matioli, G. (2007) Immobilization of Bacillus firmus Strain 37 in Inorganic Matrix for Cyclodextrin Production. Journal of Molecular Catalysis B: Enzymatic, 49, 1-7. https://doi.org/10.1016/j.molcatb.2007.07.003

[3] Pinto, F.S.T., Flôres, S.H., Ayub, M.A.Z. and Hertz, P.F. (2007) Production of Cyclodextrin Glycosyltransferase by Alkaliphilic Bacillus circulans in Submerged and Solid-State Cultivation. Bioprocess and Biosystems Engineering, 30, 377-382. https://doi.org/10.1007/s00449-007-0134-Z

[4] Moriwaki, C., Ferreira, L.R., Rodella, L.R.T. and Matioli, G. (2009) A Novel Cyclo- 
dextrin Glycosyltransferase from Bacillus sphaericus Strain 41: Production, Characterization and Catalytic Properties. Biochemical Engineering Journal, 48, 124-131. https://doi.org/10.1016/j.bej.2009.09.001

[5] Burhan, N., Sapundzhiev, T. and Beschkov, V. (2007) Mathematical Modelling of Cyclodextrin-Glucano-Transferase Production by Immobilised Cells of Bacillus circulans ATCC 21783 at Batch Cultivation. Biochemical Engineering Journal, 35, 114-119. https://doi.org/10.1016/j.bej.2007.01.021

[6] Ai-Noi, S., Abd-Aziz, S., Alitheen, N., Hassan, O. and Karim, M.I.A. (2008) Optimization Cyclodextrin Glycosyltransferase Production by Response Surface Methodology Approach. Biotechnology, 7, 10-18.

https://doi.org/10.3923/biotech.2008.10.18

[7] Sian, H.K., Said, M., Hassan, O., Kamaruddin, K., Ismail, A.F., Rahman, R.A. Mahmood, N.A.N. and Illias, R.M. (2005) Purification and Characterization of Cyclodextrin Glucanotransferase from Alkalophilic Bacillus sp. G1. Process Biochemistry, 40, 1101-1111. https://doi.org/10.1016/j.procbio.2004.03.018

[8] Abdel-Naby, M.A., El-Refai, H.A. and Abdel-Fattah, A.F. (2011) Biosynthesis of Cyclodextrin Glucosyltransferase by the Free and Immobilized Cells of Bacillus cereus NRC7 in Batch and Continuous Cultures. Journal Applied Microbiology, 111, 1129-1137. https://doi.org/10.1111/j.1365-2672.2011.05136.x

[9] Costa, G.L., Pazzetto, R., Brol, F. and Matioli, G. (2007) Metodologia de seleção de cepas para produção da ciclodextrina glicosiltransferase e para purificação da enzima. Acta Scientiarum Health Sciences, 29, 45-50.

[10] Letsididi, R., Sun, T., Mu, W., Kessy, N.H., Djakpo, O. and Jiang, B. (2011) Production of a Thermoactive Beta-Cyclodextrin Glycosyltransferase with a High Starch Hydrolytic Activity from an Alkalitolerant Bacillus licheniformis Strain Sk 13.002. Asian Journal of Biotechnology, 3, 214-225. https://doi.org/10.3923/ajbkr.2011.214.225

[11] Martins, R.F., Delgado, O. and Hatti-Kaul, R. (2003) Sequence Analysis of Cyclodextrin Glycosyltransferase from the Alkaliphilic Bacillus agaradhaerens. Biotechnology Letters, 25, 1555-1562. https://doi.org/10.1023/A:1025430532333

[12] Mazzer, C., Ferreira, L.R., Rodella, J.R.T., Moriwaki, C. and Matioli, G. (2008) Cyclodextrin Production by Bacillus firmus Strain 37 Immobilized on Inorganic Matrices and Alginate Gel. Biochemical Engineering Journal, 41, 79-86. https://doi.org/10.1016/j.bej.2008.03.010

[13] Szejtli, J. (1988) Cyclodextrin Technology. Dordrecht, Netherlands. https://doi.org/10.1007/978-94-015-7797-7

[14] Kunamneni, A., Prabhakar, T., Jyothi, B. and Ellaiah, P. (2007) Investigation of Continuous Cyclodextrin Glucanotransferase Production by the Alginate-Immobilized Cells of alkalophilic Bacillus sp. in an Airlift Reactor. Enzyme and Microbial Technology, 40, 1538-1542. https://doi.org/10.1016/j.enzmictec.2006.10.031

[15] Cabello, P.E., Scognamiglio, F.P. and Terán, F.J.C. (2009) Vinasses Treatment in Anaerobic Fluidized Bed Reactor. Journal of Environmental Engineering Course, 6, 321-338.

[16] Carvalho, W., Canilha, L. and Silva, S.S. (2006) Uso de biocatalisadores imobilizados: Uma alternativa para a condução de bioprocessos. Analytica Magazine, 23, 60-70.

[17] Guedes, T.S., Mansur, M.B. and Rocha, S.D.F. (2007) A Perspective of Bone Char Use in the Treatment of Industrial Liquid Effluents Containing Heavy Metals. XXII 
ENTMME/VII MSHMT, Ouro Preto.

[18] Postma, J., Nijhuis, E.H. and Someus, E. (2010) Selection of Phosphorus Solubilizing Bacteria with Biocontrol Potential for Growth in Phosphorus Rich Animal Bone Charcoal. Applied Soil Ecology, 46, 464-469. https://doi.org/10.1016/j.apsoil.2010.08.016

[19] Ngandwe, N. (2007) Toxicity of Animal Bone Charcoal from Pig and Cattle to Aquatic Bioassays: Vibrio Fischeri, Daphnia Magna and Selenastrum Capricornutum. Ph.D. Dissertation, Leipzig University, Leipzig.

[20] Freire, F.B. and Pires, E.C. (2004) Evaluation of the Material Support for Biomass in Fluidized Bed Reactors: Adhesion and Hydrodynamics. Magazine University Rural, Exact and Earth Sciences Series-Seropédica, 23, 34-43.

[21] Pazzeto, R., Delani, T.C.O., Fenelon, V.C. and Matioli, G. (2011) Cyclodextrin Production by Bacillus firmus Strain 37 Cells Immobilized on Loofa Sponge. Process Biochemistry, 46, 46-51. https://doi.org/10.1016/j.procbio.2010.07.008

[22] Matioli, G., Zanin, G.M., Guimarães, M.F. and Moraes, F.F. (1998) Production and Purification of CGTase of Alkalophylic Bacillus Isolated from Brazilian Soil. Applied Biochemistry and Biotechnology, 70-72, 267-275. https://doi.org/10.1007/BF02920143

[23] Nakamura, N. and Horikoshi, K. (1976) Characterization and Some Cultural Conditions of a Cyclodextrin Glycosyltransferase-Producing Alkalophilic Bacillus sp. Agricultural Biological Chemistry, 40, 753-757. https://doi.org/10.1080/00021369.1976.10862122

[24] Lowry, O.H., Rosebrough, N.J., Farr, A.L. and Randall, R.J. (1951) Protein Measurement with the Folin Phenol Reagent. Journal of Biological Chemistry, 193, 265-275.

[25] Tardioli, P.W., Zanin, G.M. and Moraes, F.F. (2000) Production of Cyclodextrins in a Fluidized-Bed Reactor Using Cyclodextrin-Glycosyltransferase. Applied Biochemistry and Biotechnology, 84-86, 1003-1019. https://doi.org/10.1385/ABAB:84-86:1-9:1003

[26] Tardioli, P.W., Zanin, G.M. and Moraes, F.F. (2006) Characterization of Thermoanaerobacter Cyclomaltodextrin Glucanotransferase Immobilized on Glyoxil-Agarose. Enzyme and Microbial Technology, 39, 1270-1278. https://doi.org/10.1016/j.enzmictec.2006.03.011

[27] Hamom, V. and Moraes, F.F. (1990) Etude preliminare a L'Immobilisation de L'Enzime CGTase WACKER. Research Report. Laboratoire de Technologie Enzymatique, Université de Technologie de Compiègne, Compiègne.

[28] Lurtwitayapont, S. and Srisatit, T. (2009) Comparison of Lead Removal by Various Types of Swine Bone Adsorbents. The International Journal Published by the Thai Society of Higher Education Institutes on Environment, 3, 32-38.

[29] Monroe, D. (2007) Looking for Chinks in the Armor of Bacterial Biofilms. PLoS Biology, 5, e307. https://doi.org/10.1371/journal.pbio.0050307

[30] Sader, L.T. (2005) Evaluation of Polymer Particles as Support Material in Anaerobic Fluidized Bed Reactor in Phenol Treatment. Ph.D. Dissertation, São Carlos Federal University, São Carlos.

[31] Vassileva, A., Beschkov, V., Ivanova, V. and Tonkova, A. (2005) Continuous Cyclodextrin Glucanotransferase Production by Free and Immobilized Cells of Bacillus circulans ATCC 21783 in Bioreactors. Process Biochemistry, 40, 3290-3295. https://doi.org/10.1016/j.procbio.2005.03.022 
[32] Atanasova, N., Kitayska, T., Yankov, D., Safarikova, M. and Tonkova, A. (2009) Cyclodextrin Glucanotransferase Production by Cell Biocatalysts of Alkaliphilic Bacilli. Biochemical Engineering Journal, 46, 278-285.

https://doi.org/10.1016/j.bej.2009.05.020

[33] Atanasova, N., Kitayska, T., Bojadjieva, I., Yankov, D. and Tonkova, A. (2011) A Novel Cyclodextrin Glucanotransferase from Alkaliphilic Bacillus Pseudalcaliphilus 20RF: Purification and Properties. Process Biochemistry, 46, 116-122. https://doi.org/10.1016/j.procbio.2010.07.027

[34] Vassileva, A., Burhan, N., Beschkov, V., Spasova, D., Radoevska, S., Ivanova, V. and Tonkova, A. (2003) Cyclodextrin Glucanotransferase Production by Free and Agar Gel Immobilized Cells of Bacillus circulans ATCC 21783. Process Biochemistry, 38, 1585-1591. https://doi.org/10.1016/S0032-9592(03)00060-8

[35] Kuo, C.C., Lin, C.A., Chen, J.Y., Lin, M.T. and Duan, K.J. (2009) Production of Cyclodextrin Glucanotransferase from an Alkalophilic bacillus sp. by $\mathrm{pH}$-Stat Fed-Batch Fermentation. Biotechnology Letters, 31, 1723-1727. https://doi.org/10.1007/s10529-009-0071-9

[36] Paulová, L., Patáková, P. and Brányik, T. (2013) Chapter 4: Advanced Fermentation Processes. In: Teixeira, J. and Vicente, A., Ed., Engineering Aspects of Food Biotechnology, CRC Press, Boca Raton: 89-105. https://doi.Org/10.1201/b15426-6

[37] Ibrahim, H.M., Yusoff, W.M.W., Hamid, A.A. and Omar, O. (2010) Enhancement of Cyclodextrin Glucanotransferase Production by Bacillus G1 Using Different Fermentation Modes. Biotechnology Journal, 9, 506-512. https://doi.org/10.3923/biotech.2010.506.512

[38] Blanco, K. Lima, C.J.B., Monti, R., Martins Jr., J., Bernardi, N.S. and Contiero, J. (2012) Bacillus lehensis-An Alkali-Tolerant Bacterium Isolated from Cassava Starch Wastewater: Optimization of Parameters for Cyclodextrin Glycosyltransferase Production. Annals Microbiology, 62, 329-337. https://doi.org/10.1007/s13213-011-0266-x

[39] Pinto, F.S.T., Flôres, S.H., Schneider, C.E., Ayub, M.A.Z. and Hertz, P.F. (2011) The Influence of Oxygen Volumetric Mass Transfer Rates on Cyclodextrin Glycosyltransferase Production by Alkaliphilic Bacillus circulans in Batch and Fed-Batch Cultivations. Food Bioprocess Technology, 4, 559-565.

https://doi.org/10.1007/s11947-009-0188-9 